IQTISHODUNA

Vol. 16 (1), 2020

P-ISSN: 1829-524X, E-ISSN: 2614-3437

\title{
Strategi Produk Rekayasa Umum untuk Meningkatkan Market Share Dalam Negeri dengan Metode Delphi
}

\author{
Olin Lintang Pribadi \\ Fakultas Ekonomi dan Bisnis, Universitas Airlangga, Indonesia \\ E-mail: olinlintang@gmail.com
}

\begin{abstract}
This study aims to determine the cause of the low market share of general engineering products at PT PAL Indonesia. Market share analysis is considered important in winning business competition. The study uses qualitative descriptive methods and subject data in the form of opinions, attitudes, experiences or characteristics of a person or group of people who are the research subjects or informants. Source of data used are primary data derived from informant interviews and secondary data derived from supporting documents relevant to the study. To find out the root of the problem using the technique of root causes analysis with the fishbone method and find alternative solutions to the problem with the Delphi method in the form of a questionnaire to the experts. The results of the study explained that the low market share of general engineering products is found in every indicator of fishbone, namely: machine, method, material, manpower, measurement and mother nature. And in the opinion of the experts there is no significant difference of opinion in providing alternative solutions to every problem on the fishbone indicator. So the company can be used in making policies.
\end{abstract}

Keywords: market share, marketing business strategy, fishbone and Delphi methods.

\begin{abstract}
Abstrak: Penelitian ini bertujuan untuk mengetahui penyebab rendahnya market share produk rekayasa umum di PT PAL Indonesia. Analisis market share dinilai penting dalam memenangkan persaingan bisnis. Penelitian menggunakan metode diskriptif kualitatif dan data subjek yang berupa opini, sikap, pengalaman atau karakteristik dari seseorang atau sekelompok orang yang menjadi subjek penelitian atau informan. Sumber data yang digunakan adalah data primer yang berasal dari wawancara informan dan data sekunder berasal dari dokumen pendukung yang relevan dengan peneletian. Untuk mengetahui akar permasalahan menggunakan teknik root causes analysis dengan metode fishbone dan mencari alternatif solusi dari permasalahan tersebut dengan metode delphi berupa kuisioner pada para ahli. Hasil penelitian menjelaskan bahwa rendahnya market share produk rekayasa umum ada pada setiap indikator fishbone yaitu: machine, method, material, manpower, measurement dan mother nature. Dan dalam pendapat para ahli tidak ada perbedaan pendapat yang signifikan dalam memberikan alternatif solusi dari setiap permasalahan pada indikator fishbone. Sehingga dapat digunakan perusahaan dalam mengambil kebijakan.
\end{abstract}

Kata kunci: market share, strategi bisnis pemasaran, metode fishbone, delphi. 
| Draft awal November 2019 |Diterima April 2020 | Terbit April 2020 |

| DOI: http://dx.doi.org/10.18860/iq.v16i1.8049

\section{Cara mencitasi:}

Pribadi, O.L. (2020). Strategi Produk Rekayasa Umum untuk Meningkatkan Market Share Dalam Negeri dengan Metode Delphi. Iqtishoduna. Vol. 16 (1): pp 83-100.

\section{Pendahuluan}

Indonesia sebagai negara poros maritim dunia, memiliki daratan seluas 1.922 .570 kilometer persegi $(37,11 \%)$ dan perairan seluas 3.257 .483 kilometer persegi $(62,89 \%)$ maka, industri perkapalan dan galangan kapal memiliki peran strategis dalam pembuatan sarana transportasi laut dan menjaga ketahanan wilayah negara. Pemerintah telah menyusun road map Tahun 2012 - 2025 dengan membuat wilayah klaster industri perkapalan nasional yang memiliki kapasitas produksi 2.000.000 (Dead Weight Tons/DWT), didukung dengan industri komponen kapal yang tangguh dan berdaya saing.

Jumlah galangan kapal di Indonesia mencapai 250 perusahaan dimana 4 diantaranya berstatus BUMN yaitu: PT PAL Indonesia, PT Dok Kodja Bahari (DKB), PT Dok dan Perkapalan Surabaya (DPS), dan PT Industri Kapal Indonesia (IKI) dengan total kapasitas terpasang bangunan baru sebesar 936.000 DWT (dead weight tons/DWT) pertahun, dan reparasi kapal 12.150.000 DWT pertahun. Analisis kemampuan daya saing dan penguatan perusahaan galangan kapal nasional harus dilihat dari konteks persaingan pasar global, khususnya galangan kapal kelas menengah ke atas, karena potensi pasar lokal menjadi bagian dari pasar global khususnya di kawasan Asia Pasifik (Ma'ruf, 2006).

Industri galangan kapal (shipyard) di Indonesia sudah ada sejak lama, diawali dengan pendirian Galangan Kapal Marina oleh Pemerintah Belanda pada Tahun 1939 di Surabaya. Pada tanggal 15 April 1980 diganti namanya menjadi PT PAL (Penataran Angkatan Laut), dan sekarang menjadi PT PAL Indonesia (Persero). Berlokasi di Ujung Surabaya dengan luas $120 \mathrm{Ha}$, menjadikan perusahaan ini memiliki lokasi strategis. Dalam perkembangan perusahaan, pada tahun 1986 bidang bisnis PT PAL diperluas menjadi 4 divisi yaitu: Divisi Pemeliharaan dan Perbaikan (Harkan), Divisi Kapal Perang, Divisi Kapal Niaga, dan Divisi General Engineering (GE) atau 
rekayasa umum.

Realisasi penjualan produk PT PAL Indonesia mengalami fluktuatif dalam kurun waktu lima tahun. Realisasi penjualan belum mencapai target yang sudah ditetapkan, pada tahun 2018 perusahaan mampu mendapat sales sebesar Rp 1,582 miliar yang dikontribusi oleh produk alutsista sebesar 46\% dari keseluruhan portofolio bisnis perusahaan. Produk alutsista memiliki kontribusi penjualan paling tinggi karena didukung UU No. 16 Tahun 2012 yang menjelaskan bahwa PT PAL Indonesia sebagai pemandu utama (lead integrator) yang memiliki kewajiban untuk berperan aktif dalam mendukung pemenuhan kebutuhan alutsista matra laut.

Persaingan industri sejenis semakin ketat dimana pesaing mulai mampu menunjukkan eksistensi dari produk yang dihasilkan sehingga mempengaruhi pertumbuhan penjualan perusahaan selain produk alutsista yaitu kapal niaga, rekayasa umum dan pemeliharaan perbaikan. Nilai yang paling rendah pada market share, untuk produk rekayasa umum menunjukkan perusahaan harus menjaga daya saingnya dan mengembangkan strategi bisnis yang kompetitif. Produk dengan marketshare terendah dapat dijadikan fokus bisnis untuk mengambil langkah strategis dalam mengembangkan lini produk bisnis perusahaan. Dari data tersebut produk rekayasa umum (rekum) hanya menguasai pasar sebesar 3,19\% dan menjadi followers perusahaan pesaing lainnya.

Pasar produk rekayasa umum terbagi dalam pasar migas dan non migas. Produk rekayasa umum yang dibuat PT PAL Indonesia terbagi dalam pengembangan bidang energy, oil and gas. Kontribusi dua tahun terakhir produk rekayasa umum terhadap perusahaan menunjukkan peningkatan yang signifikan, karena mendapat satu proyek tertentu dengan jumlah yang sangat besar. Tetapi secara pangsa pasar penguasaan masih tergolong rendah. Analisis secara terstruktur dan menyeluruh diperlukan untuk mengetahui penyebab permasalahan rendahnya market share produk rekayasa umum di PT PAL Indonesia. Selain itu diperlukan penerapan strategi bisnis yang tepat dalam menghadapi perubahan lingkungan bisnis yang tidak pasti, guna peningkatan market share produk rekayasa umum dalam negeri.

Perubahan lingkungan bisnis yang sangat cepat (turbulence) mengakibatkan tingginya dinamika lingkungan yang selanjutnya menimbulkan ketidakpastian lingkungan bisnis. Selain itu, strategi yang digunakan juga harus efektif, yakni strategi tersebut mampu mendorong terciptanya suatu keselarasan yang sempurna antara organisasi dengan 
lingkungannya dan antara organisasi dengan pencapaian dari tujuan strategisnya (Griffin, 2004). Pangsa pasar sering digunakan untuk menggambarkan posisi dan keberhasilan perusahaan dalam sektor industri, sehingga dapat ditafsirkan bahwa pangsa pasar mempengaruhi pemikiran organisasi dan perencanaan strategis. Hubungan strategi dan peningkatan pangsa pasar menunjukkan kinerja yang lebih baik dan khususnya keuangan, retensi dan kepuasan pelanggan. Untuk memastikan keunggulan kompetitif, perusahaan perlu mempertimbangkan pangsa pasar dengan perbandingan tingkat keuntungan. Berdasarkan hal tersebut penelitian ini bertujuan untuk menemukan penyebab rendahnya market share produk rekayasa umum di PT PAL Indonesia dan memberikan alternatif strategi bisnis produk rekayasa umum yang harus dikembangkan PT PAL Indonesia untuk meningkatkan market share dalam negeri.

\section{Kajian Pustaka \\ Strategi}

Strategi menjadi awal penentu untuk menentukan keberlangsungan hidup suatu perusahaan. Menurut David (2016) strategi merupakan cara untuk mencapai sasaran strategis jangka panjang. Strategi disusun sebagai pedoman jangka panjang perusahaan dalam mencapai tujuan yang ditetapkan. Penyusunan strategi dalam jangka panjang membutuhkan perencanaan atau fortmulasi yang tepat. Tahapan perencanaan strategi dilakukan dengan menghasilkan misi, visi, nilai dasar dan tujuan perusahaan.

Manajemen penerapan strategi diperlukan manajemen yang tepat agar formulasi strategi yang disusun mampu mewujudkan eksekusi strategi sesuai tujuan dan target perusahaan. Manajemen strategi adalah serangkaian keputusan dan tindakan manajerial (wheelen \& Hunger, 2004) yang dihasilkan dari proses formulasi dan implementasi rencana (Pearce \& Robinson, 2008) dengan tujuan menciptakan keunggulan kompetitif. Menurut David (2016) proses manajemen strategi terdiri dari tiga tahap yaitu: pertama formulasi strategi yang mencakup pengembangan visi dan misi, mengidentifikasi kesempatan dan ancaman ekternal organisasi, menentukan kekuatan dan kelemahan organisasi, menciptakan tujuan jangka panjang, memulai strategi alternatif, dan memilih strategi khusus untuk dicapai.

Menurut Rangkuti (2017) tujuan utama perencanaan strategis adalah agar perusahaan dapat melihat secara objektif kondisi internal dan eksternal, sehingga perusahaan dapat mengantisipasi perubahan lingkungan ekternal. Tahap kedua adalah mengimplementasikan strategi yang mencakup 
pengembangan budaya suportif strategi, penciptaan struktur organiasi yang efektif, pengarahan kembali usaha pemasaran, persiapan anggaran, pengembangan dan penggunaan sistem organisasi, dan pengaitan sistem karyawan dan kinerja organisasi. Sebagai kelemahan dalam bidang strategi penyebab kegagalan adalah proses implementasi dan pengembangan strategi itu sendiri. Tahap terakhir adalah melakukan evaluasi strategi yang mencakup aktivitas peninjauan faktor internal dan ekternal yang menjadi basis strategi, mengukur kinerja, dan mengambil tindakan korektif. Evaluasi strategi dibutuhkan karena menjadi dasar acuan menentukan kebijakan manajemen strategik.

\section{Pemasaran}

Pemasaran merupakan hal penting dalam suatu usaha, pemasaran dapat dikatakan proses output dari suatu produk agar sampai ke konsumen. Pemasaran merupakan kegiatan usaha yang bertalian dengan arus penyerahan barang atau jasa dari produsen ke konsumen (Mursid, 2015). Menurut Kotler \& Armstrong (2008), pemasaran adalah sebuah proses perusahaan menciptakan nilai untuk konsumennya dan membangun hubungan kuat dengan konsumen yang bertujuan untuk menciptakan nilai keuntungan dari konsumen. Dalam kegiatan pemasaran pelaku usaha harus mempunyai strategi yang tepat dan menyesuaikan kemampuan.

Strategi pemasaran yang digunakan bertujuan untuk membangun hubungan dengan pelanggan dan sebagai pembeda dengan pesaing. Menurut Kotler \& Armstrong (2008), strategi pemasaran adalah logika pemasaran dimana unit bisnis berharap untuk menciptakan nilai dan mendapatkan keuntungan dari hubungan dengan konsumen. Penerapan strategi pemasaran perusahaan harus menyesuaikan kondisi internal dan ekternal perusahaan. Kondisi internal menyesuaikan kapabilitas dan kemampuan sumber daya, sedangkan kondisi eksternal melihat perubahan daya saing dan permintaan pasar.

Strategi pemasaran yang efektif diperlukan perusahaan untuk memenangkan persaingan. Strategi Pemasaran merupakan pernyataan (secara implisit maupun eksplisit) mengenai bagaimana suatu merek atau lini produk mencapai tujuannya. Tujuan utama sebagian besar perusahaan yang tercermin dalam strategi pemasaran adalah mendapatkan keuntungan yang maximal. Untuk memenuhi kriteria profitabilitas, produk baru diluncurkan ke pasar dengan tujuan mencapai pangsa pasar setinggi mungkin dan menjadi pemimpin pasar. Strategi ini menyiratkan bahwa dominasi pasar sangat penting untuk memungkinkan perusahaan untuk meraup imbalan dari skala ekonomi dan untuk memaksimalkan profitabilitas 
melalui pendapatan penjualan yang dimaksimalkan dan menekan biaya karena dianggap bahwa profitabilitas mengikuti pangsa pasar.

\section{Market Share}

Pangsa pasar (market share) dapat diartikan sebagai bagian pasar yang dikuasai oleh suatu perusahaan, atau prosentasi penjualan suatu perusahaan terhadap total penjualan para pesaing terbesarnya pada waktu dan tempat tertentu (William, 1984). Besarnya pangsa pasar setiap saat akan berubah sesuai dengan perubahan selera konsumen, atau berpindahnya minat konsumen dari suatu produk ke produk lain (Charles et al., 2001). Kotler \& Keller (2016) menyatakan bahwa peta perusahaan dalam perusahaan menduduki posisi persaingan dapat terbagi sebagai berikut: perusahaan bersifat dominan jika mampu mengendalikan strategi pesaing dan memiliki banyak pilihan strategi untuk diterapkan. Perusahaan bersifat kuat (strong) jika memiliki kekuatan sehingga bisa menggunakan strategi tertentu untuk memenangkan persaingan. Perusahaan bersifat Baik jika kekuatan yang bisa dimanfaatkan dengan strategi tertentu sesuai target pesaing. Perusahaan bersifat sedang (tenable) jika memiliki kekuatan dan prestasi yang cukup untuk tetap menjalankan strategi usahanya. Perusahaan bersifat lemah (weak) jika memiliki prestasi yang tidak memuaskan, tapi memiliki peluang untuk memperbaiki strateginya. Perusahaan bersifat tidak ada harapan (NonViable) jika perusahaan mendapatkan prestasi yang tidak memuaskan.

Perusahaan memiliki beberapa peran penting didalam menjalankan usahanya terkait posisi dalam penguasaan pasar yang terbagi sebagai berikut:

1. Pemimpin Pasar (Market Leader)

a. Memiliki ceruk pasar yang terbesar (40\%)

b. Lebih unggul dalam hal pengenalan produk baru, perubahan harga, cakupan saluran distribusi, dan intensitas promosi

c. Merupakan pusat rujukan pesaing

2. Penantang Pasar (market Challenger)

a. Merupakan perusahaan besar dengan ceruk pasar $\pm 30 \%$

b. Berusaha mencari kelemahan pemimpin pasar, sehingga bisa menyerangnya

c. Berusaha mengambil alih perusahaan yang lemah

d. Pengikut Pasar (market follower)

e. Menonjolkan ciri khasnya kepada pasar sasaran

f. Meniru produk atau strategi pemimpin pasar dan penantang pasar

g. Memperoleh laba yang tinggi karena tidak menanggung beban inovasi

3. Penggarap Ceruk Pasar (Market Nicher)

88 | IQTISHODUNA Vol. 16 (1), 2020

http://ejournal.uin-malang.ac.id/index.php/ekonomi 

a. Spesialiasi berdasarkan geografis
b. Perusahaan dengan daya beli dan ukuran yang cukup besar
c. Memiliki potensi untuk berkembang
d. Memiliki keterampilan dan sumber daya yang cukup
e. Mampu mempertahankan diri

Secara sederhana pangsa pasar merupakan persentase dari luasnya total pasar yang dapat dikuasai oleh suatu perusahaan. Market share dalam praktik bisnis merupakan acuan, karena perusahaan dengan nilai pangsa pasar yang lebih baik akan menikmati keuntungan dan penjualan produk dengan lebih baik pula ketimbang pesaingnya.

\section{Metodologi Penelitian}

Penelitian ini menggunakan metode deskriptif kualitatif, dimana memiliki kesamaan dengan desain deskriptif kuantitatif karena itu biasa disebut kualitatif semu. Desain penelitian kualitatif bertujuan untuk menggambarkan, meringkas berbagai kondisi, situasi, fenomena realitas sosial, yang menjadi obyek penelitian di masyarakat dan berupaya menarik realitas ke permukaan sebagai ciri, karakter, sifat, model, tanda, atau gambaran tentang kondisi, situasi, ataupun fenomena tertentu (Bungin, 2014).

Unit analisis yang menjadi fokus penelitian kualitatif berlaku khusus artinya generalisasi hasil tidak berlaku untuk populasi luas, melainkan diterapkan pada populasi yang mempunyai karakteristik sama dengan obyek penelitian. Obyek penelitian ini adalah produk divisi rekayasa umum yang dianalisis penyebab rendahnya market sharenya dan memberikan saran alternatif strategi guna meningkatkan market share dalam negeri yang harus dikembangkan PT PAL Indonesia.

Jenis data yang digunakan dalam penelitian ini adalah data subjek yang berupa opini, sikap, pengalaman atau karakteristik dari seseorang atau sekelompok orang yang menjadi subjek penelitian atau informan (Sugiyono, 2013). Data subjek dalam penelitian ini diperoleh dari sumber data primer dan sekunder. Sumber data primer diperoleh secara langsung melalui wawancara mendalam dengan informan guna mengetahui penyebab permasalahan penelitian yaitu rendahnya market share produk rekum di PT PAL Indonesia dan penyebaran kuisioner dengan metode Delphi untuk memperoleh pendapat para ahli tentang alternatif strategi bisnis yang dikembangkan PT PAL Indonesia guna meningkatkan market share produk rekayasa umum dalam negeri. Sumber data sekunder diperoleh dari analisis dan interpretasi 
dari dokumen pendukung secara teori, metode penelitian, permusan hasil dan pembahasan serta rekomedasi melalui referensi buku, suratkabar, website dan laporan perusahaan yang relevan dengan penelitian.

Penelitian tahap awal dilakukan dengan melakukan analisa pokok permasalahan yang mencari penyebab dengan metode root cause analysis, metode tersebut digunakan dengan teknik fishbone yang mengidentifikasi pokok permasalahan berdasarkan kategori tertentu. Obyek penelitian merupakan industri manufaktur yang memiliki kategori $6 \mathrm{M}$ yaitu machine, method, material, man power, measurement, dan mother nature.

Identifikasi permasalahan diperoleh dengan melakukan wawancara secara mendalam yang melibatkan Divisi rekayasa umum, yang memahami aspek secara menyeluruh tentang produk rekayasa umum di PT PAL Indonesia. Selanjutnya pokok permasalahan diidentifikasi dan dikombinasi dalam pertanyaan kuisioner dengan metode Delphi. Metode Delphi dikembangkan untuk meminta pendapat atau tanggapan para ahli secara internal dan ekternal dan memberikan alternatif solusi strategi bisnis bagi PT PAL Indonesia yang komprehensif guna meningkatkan market share produk rekayasa umum.

Penerapan Metode Delphi dalam penelitian dilakukan dalam beberapa putaran yang memiliki tahapan sama guna memperoleh kesepakatan pendapat dan alternatif solusi. Dalam penelitian kualitatif ini menggunakan uji keabsahan yang bersifat konstruk. Keabsahan konstruk (construct validity) adalah keabsahan bentuk batasan berkaitan dengan suatu kepastian bahwa yang berukur merupakan variabel yang ingin diukur. Penelitian ini menggunakan triangulasi data dari berbagai sumber data seperti dokumen, arsip, hasil wawancara, dan hasil observasi. Metode Delphi dilakukan dalam beberapa putaran sampai mencapai konsensus atau kesepakatan dan alternatif saran dari setiap permasalahan. Sehingga hasil triangulasi metode dapat mendukung hasil akhir penelitian.

\section{Hasil Penelitian}

Tahap awal hasil penelitian yang dilakukan adalah hasil analisis rendahnya market share produk rekayasa umum di PT PAL Indonesia menggunakan root causes analysis dengan teknik fishbone yaitu: machine, method, material, manpower, measurement dan mother nature. Data permasalahan diperoleh dengan wawancara kepada pihak internal yaitu empat manajer divisi rekayasa umum dan pihak ekternal perusahaan yang terdiri dari dua konsumen guna mengetahui dasar permasalahan rendahnya 
market share produk rekayasa umum di PT PAL Indonesia. Teknik fishbone memberikan panduan analisis akar permasalahan yang terdiri dari beberapa indikator $6 \mathrm{M}$ yaitu (machine, method, material, manpower, measurement dan mother nature), yang selanjutnya dipilih pertanyaan faktor pendukung untuk menjelaskan indikator pada machine, method, material, manpower, measurement dan mother nature.

Dari hasil penelitian diperoleh penyebab kemungkinan dari setiap indikator fishbone dari pendapat informan yang sudah diolah, sehingga dapat dijelaskan sebagai berikut, machine berfokus pada peralatan produksi yang memiliki empat permasalahan pada mesin yaitu kondisi mesin banyak yang mengalami kerusakan, karena sudah berusia tua atau ketinggalan zaman dan memerlukan pembiayaan ekstra untuk melakukan perawatan dan perbaikan. Dan diperlukan untuk mendukung keandalan mesin, sehingga memiliki performa yang baik.

Pada fokus penerapan teknologi terkini memiliki dua permasalahan yaitu perlu ditambahkan software baru untuk update teknologi dan penerapan kontrol dengan program maintenance. Method berfokus pada standart proses produksi memiliki dua permasalahan yaitu proses pengelolaan sisa material dan pelaporan manufacturing data report project. Sedangkan pada pengujian dan pengendalian hasil produk memiliki dua permasalahan yaitu kebutuhan man power untuk setting produksi dan ketergantungan pada pihak ketiga terkait pengujian alat dengan spesifikasi khusus.

Material berfokus pada perolehan material memiliki satu permasalahan yaitu keterlambatan raw material dan sparepart. Man power berfokus pada pemenuhan dan pengolahan SDM memiliki dua permasalahan yaitu kurangnya SDM dan SDM tenaga subkon yang memiliki keterampilan khusus. Sedangkan pengembangan kompetensi SDM juga memiliki dua permasalahan yaitu implementasi pengajuan pelatihan yang tidak sesuai permintaan dan transfer knowledge antar generasi.

Measurement berfokus pada standar produk sesuai keinginan pelanggan memiliki empat permasalahan yaitu perolehan dan biaya sertifikasi produk dan standar produk oil dan gas, komponen material yang disediakan dan terdapat kendala pemasangan komponen meski ada partikel kecil. Sedangkan perawatan dan kalibrasi pada peralatan produksi memiliki dua permasalahan yaitu kebutuhan tenaga ahli internal untuk melakukan kalibrasi dan apabila pengujian kalibrasi yang melibatkan pihak ketiga. 
Mother nature yang berfokus pada pemilahan limbah B3 memiliki satu permasalahan yaitu proses masih dilakukan secara manual dan tidak ada tempat khusus untuk mengolah. Penerapan budaya 5R tidak ditemukan adanya permasalahan. Dari penjabaran tersebut diatas untuk memperkuat hasil penelitian, maka dilanjutkan dengan teknik metode delphi. Metode delphi dilakukan dengan mencari konsensus pendapat dan saran para ahli dibidangnya baik dari segi internal dan ekternal perusahaan dengan dua putaran pertanyaan pada kuisioner, untuk mengetahui solusi yang diberikan dari setiap indikator permasalahan dari fishbone. Hasil dari Metode Delphi dapat dilihat pada Tabel 1.

\section{Pembahasan}

Berdasarkan pendapat dari beberapa pakar mengenai indikator Fishbone, dapat diuraikan hasilnya sebagai berikut: pada aspek mesin ditinjau dari Peralatan produksi, diperoleh kesimpulan bahwa Kerusakan banyak terjadi pada mesin utama dan sparepart yang sudah berumur lebih dari 10 tahun, sehingga diperlukan kontrol dan perawatan secara rutin; Kondisi mesin banyak yang sudah tua tetapi masih membutuhkan revitalisasi teknologi dengan tingkat produktifitas untuk memenuhi pangsa pasar saat ini; Pembiayaan mesin diperlukan pada perbaikan dan perawatan sesuai dengan seleksi yang direncanakan perusahaan dalam jangka panjang atau sebagai biaya rutin dalam perhitungan HPP; ditinjau dari penerapan teknologi diperoleh kesimpulan Penambahan software diperlukan sesuai dengan kompetensi inti dan tuntutan bisnis yang disesuaikan dengan kebutuhan operasional dari teknologi yang digunakan.

Apabila ditinjau dari metode diperoleh kesimpulan bahwa pengelolaan sisa material harus dilakukan sesuai SO yang berlaku; Pelaporan manufactuirng data report diperlukan dukungan dari Divisi Jaminan Kualitas untuk mendukung produktivitas; Diperlukan supply manpower untuk set produksi sesuai kebutuhan dan kompetensi yang memadai.

Jika ditinjau dari material diperoleh kesimpulan bahwa keterlambatan material dan sparepart khususnya produk impor harus diatasi dengan kecepatan administrasi internal dan pemasok yang terpercaya. Dilihat dari segi man power diperoleh kesimpulan Ketersediaan SDM harus disesuaikan dengan kebutuhan dan kompetensi untuk mendukung arah bisnis kedepan; Ketersediaan SDM subkon harus dikualifikasi khusus sesuai kebutuhan dan dikelola secara profesional; Implementasi pengajuan pelatihan disesuaikan kebutuhan dan anggaran perusahaan. 
Dilihat dari sisi pengukuran diperoleh kesimpulan bahwa penyesuaian standart produk international dibuat sesuai ketentuan trend produk pasar kedepan; Penyesuaian standart produk oil dan gas yang berlaku dan sesuai kebutuhan pasar; Komponen material yang disediakan konsumen harus sesuai spesifikasi. Selanjutnya jika dilihat dari Mother Nature diperoleh kesimpulan Pemilahan limbah B3 memerlukan tempat penampungan sesuai ketentuan dan mengurangi ketergantungan pada pihak ketiga.

Selanjutnya hasil penelitian yang didukung data tersebut akan disampaikan pada para ahli dibidangnya dalam bentuk kuisioner dengan metode delphi dengan beberapa putaran untuk memperoleh pendapat dan kesepakatan saran dari permasalahan pada setiap indikator fishbone, sehingga diperoleh data seperti yang ditampilkan pada Tabel 2.

\section{Kesimpulan}

Berdasarkan hasil penelitian dan pembahasan, maka kesimpulan yang bisa diambil dengan teknik Fishbone yang berpengaruh pada penguasaan market share produk rekayasa umum di PT PAL Indonesia disebabkan oleh: tidak tersedia mesin yang sesuai klasifikasi produk untuk memenuhi keinginan konsumen khususnya dari segi penerapan teknologi terkini. Mesin masih harus dibeli atau diperbaiki. Kebanyakan produk rekayasa umum yang dipesan berupa inovasi baru dan peningkatan kapasitas produksi. Sehingga kurang bersaing dalam mesin yang berteknologi tinggi, padahal produk rekayasa umum yang berkembang saat ini sudah menggunakan optimasi mesin yang lebih canggih.

Kurangnya ketersediaan SDM yang sesuai klasifikasi dalam memenuhi proses produksi dan pelayanan masa garansi. Perusahaan masih mengalami kendala jika ada konsumen yang membutuhkan pelayanan garansi purna jual dari produk yang dibeli, sehingga berpengaruh pada pelayanan prima purna jual. Hal ini akan berpengaruh pada repeatorder produk selanjutnya.

Perusahaan masih mengalami kesulitan dalam bekerjasama dengan pemasok material produk rekayasa umum yang berasal dari impor, sehingga menganggu proses produksi dan ketepatan penyerahan. Hal ini akan berpengaruh pada repeat order produk selanjutnya.

Perusahaan masih mengalami kendala dalam melakukan uji kalibarasi produk baik saat proses produksi dan pelayanan purna jual karena terkendala ketersediaan peralatan dan sumber daya manusia. Hal ini akan berpengaruh pada repeat order produk selanjutnya.

Perusahaan harus mengikuti semua standart produk rekayasa umum baik secara nasional dan internasional guna meningkatkan daya saing. Hal 
tersebut akan berpengaruh pada bukti kualitas produk agar lebih bersaing di pasaran.

Pada pendapat para ahli yang diperoleh dari kuisioner dengan teknik Delphi diperoleh tanggapan dan saran dari segi machine, method, material, manpower, measurement dan mother nature. Tidak ada perbedaan tanggapan yang signifikan sehingga, diharapkan tanggapan dan saran tersebut dapat membangun konsensus dari manajemen internal perusahaan untuk dijadikan alternatif solusi dari rendahya market share produk rekayasa umum dari segi analisis internal perusahaan. Dalam jangka panjang permasalahan tersebut dapat berubah dan berkembang sesuai fokus bisnis perusahaan dan kondisi persaingan di pasaran

\section{Daftar Pustaka}

Bungin, B. (2014). Penelitian Kualitatif Komunikasi, Ekonomi, Kebijakan Publik dan Ilmu Sosial Lainnya. Jakarta: Kencana Prenadamedia Group.

Charles Lamb, W.et.al. (2001). Pemasaran. Edisi Pertama. Jakarta: Salemba Empat.

David, F. R. (2016). Strategic Management Consepts and Cases 15 th edition. New Jersey: Prentice Hall.

Griffin, R. W. (2004). Manajemen. Jilid I. alih bahasa Gina Gania, Ed. Wisnu Chandra Kristiaji. Jakarta: Erlangga.

Kotler, Pilip dan Gary, Armstrong. (2008). Prinsip-prinsip Pemasaran. Alih Bahasa Imam Nurmawan Jakarta : Erlangga.

Kotler, Philip and Kevin Lane Keller. (2016) Marketing Management. 15 th Edition New Jersey: Pearson Prentice Hall Intl.

Ma'ruf, B. (2006). A Systematic Approach To Strategy Formulation For Medium-Sized Shipyards. Research of BBPT.

Mursid. (2015). Manajemen Pemasaran. Jakarta: Bumi Aksara

Pearce, A. J., \& Robinson, R. B. (2008). Strategic Management; formulation, implementation and control. Mc Graw- Hill: Business and Economic.

Pearce, A. J., \& Robinson, R. B. (2018). Manajemen Strategi 10. Jakarta: Salemba Empat.

Rangkuti, F. (2017). Teknik Membedah Kasus Bisnis Analisis SWOT. Jakarta: PT. Gramedia Pustaka Utama.

Sugiyono. (2013). Metodologi Penelitian Kuantitatif, Kualitatif dan R\&D. Bandung: ALFABETA.

Wheelen, \& Hunger. (2004). Strategic Management and Business Policy. New Jersey: Pearson Prentice Hall.

William J. Stanton. (1984). Prinsip Pemasaran. Jakarta. Erlangga

94 | IQTISHODUNA Vol. 16 (1), 2020

http://ejournal.uin-malang.ac.id/index.php/ekonomi 


\section{Lampiran}

Lampiran Tabel 1. Hasil Tanggapan Ahli dengan Metode Delphi

\begin{tabular}{|c|c|c|c|c|}
\hline No & & bone & Kemungkinan & Kesimpulan Tanggapan \\
\hline 1 & Machine & $\begin{array}{l}\text { Peralatan } \\
\text { produksi }\end{array}$ & $\begin{array}{l}\text { Mesin banyak yang } \\
\text { mengalami } \\
\text { kerusakan }\end{array}$ & $\begin{array}{l}\text { Kerusakan banyak terjadi } \\
\text { pada mesin utama dan spare } \\
\text { part yang sudah berumur } \\
\text { lebih dari } 10 \text { tahun, sehingga } \\
\text { diperlukan kontrol dan } \\
\text { perawatan secara rutin }\end{array}$ \\
\hline & & & $\begin{array}{l}\text { Mesin sudah banyak } \\
\text { yang tua dan } \\
\text { ketinggalan zaman }\end{array}$ & $\begin{array}{l}\text { Kondisi mesin banyak yang } \\
\text { sudah tua; } \\
\text { membutuhkan revitalisasi } \\
\text { teknologi dengan tingkat } \\
\text { produktifitas } \\
\text { memenuhi pangsa pasar saat } \\
\text { ini }\end{array}$ \\
\hline & & & $\begin{array}{l}\text { Memerlukan } \\
\text { pembiayaan ekstra } \\
\text { untuk melakukan } \\
\text { perbaikan dan } \\
\text { perawatan }\end{array}$ & $\begin{array}{l}\text { Pembiayaan mesin } \\
\text { diperlukan pada perbaikan } \\
\text { dan perawatan sesuai dengan } \\
\text { seleksi yang direncanakan } \\
\text { perusahaan dalam jangka } \\
\text { panjang atau sebagai biaya } \\
\text { rutin dalam perhitungan HPP }\end{array}$ \\
\hline & & & $\begin{array}{l}\text { Diperlukan } \\
\text { keandalan mesin } \\
\text { yang selalu } \\
\text { mempunyai } \\
\text { performance baik }\end{array}$ & $\begin{array}{lcr}\text { Keandalan } & \text { mesin } & \text { harus } \\
\text { didukung } & \text { SDM } & \text { yang } \\
\text { berkompeten } & & \text { untuk } \\
\text { menjamin } & \text { mutu } & \text { dan } \\
\text { ketepatan } & & \text { waktu } \\
\text { penvelesaian } & & \end{array}$ \\
\hline & & $\begin{array}{l}\text { Penerapan } \\
\text { teknologi } \\
\text { terkini }\end{array}$ & $\begin{array}{l}\text { Perlu ditambahkan } \\
\text { software baru untuk } \\
\text { update teknologi }\end{array}$ & $\begin{array}{l}\text { Penambahan software } \\
\text { diperlukan sesuai dengan } \\
\text { kompetensi inti dan tuntutan } \\
\text { bisnis yang disesuaikan } \\
\text { dengan } \\
\begin{array}{l}\text { operasional dari teknologi } \\
\text { yang digunakan }\end{array}\end{array}$ \\
\hline & & & $\begin{array}{l}\text { Proses control dan } \\
\text { program } \\
\text { maintenance }\end{array}$ & $\begin{array}{l}\text { Proses control dan } \\
\text { maintenance diperlukan plan } \\
\text { maitenance system atau } \\
\text { software sesuai kebutuhan }\end{array}$ \\
\hline 2 & Method & $\begin{array}{l}\text { Standart } \\
\text { proses } \\
\text { produksi }\end{array}$ & $\begin{array}{l}\text { Pengelolaan sisa } \\
\text { material }\end{array}$ & $\begin{array}{l}\text { Pengelolaan sisa material } \\
\text { harus dilakukan sesuai So } \\
\text { yang berlaku }\end{array}$ \\
\hline & & & Pelaporan & manufactuirng \\
\hline & & & $\begin{array}{l}\text { Manufacturing Data } \\
\text { Report }\end{array}$ & $\begin{array}{l}\text { data report diperlukan } \\
\text { dukungan dari Divisi Jaminan } \\
\text { Kualitas untuk mendukung }\end{array}$ \\
\hline
\end{tabular}

IQTISHODUNA Vol. 16 (1), 2020 | 95

http://ejournal.uin-malang.a c.id/index.php/ekonomi 
Pengujian Supply manpower Diperlukan supply manpower dan untuk set produk pengendal ian hasil produk

Ketergantungan pada pihak ketiga untuk pengujian alat khusus

3 Material

4 Man Power

$\begin{array}{ll}\text { Pemenuha } & \text { Kurangnya } \\ \text { n dan } & \text { ketersediaan SDM } \\ \text { pengelolaa } & \\ \text { n SDM } & \end{array}$

Perolehan

Keterlambatan material sparepart

Pengemba

ngan

kompeten si SDM

5 Measure Standart ment
Kurangnya ketersediaan subkon dengan kualifikasi khusus Implementasi pengajuan pelatihan yang tidak sesuai permintaan

Permasalahan transfer knowledge antar generasi untuk set produksi sesuai kebutuhan dan kompetensi yang memadai

Ketergantungan pada pihak ketiga untuk melakukan pengujian alat khusus diperlukan survey untuk mendukung sinergi dan efisiensi

raw Keterlambatan material dan dan sparepart khususnya produk impor harus diatasi dengan kecepatan administrasi internal dan pemasok yang terpercaya

Ketersediaan SDM harus disesuaikan dengan kebutuhan dan kompetensi untuk mendukung arah bisnis kedepan

Ketersediaan SDM subkon harus dikualifikasi khusus sesuai kebutuhan dan dikelola secara profesional Implementasi pengajuan pelatihan disesuaikan kebutuhan dan anggaran perusahaan

Permasalahan transfer knowledge disebabkan karena proses regenarasi yang terlambat dan tidak dalam kelompok kerja yang berkesinambu ngan

Standart sertifikasi Penyesuaian standart produk produk (ASME) international dibuat sesuai

\section{produk}

sesuai

keinginan

pelanggan ketentuan trend produk pasar kedepan

Standart produk oil Penyesuaian standart produk dan gas oil dan gas yang berlaku dan sesuai kebutuhan pasar

Komponen material Komponen material yang 
Strategi Produk Rekayasa Umum...

ada yang disediakan konsumen, mengalami kendala saat dilakukan pemasangan

Pemasangan komponen masuknya kecil dengan selisih mikron

Perawatan Tenaga ahli internal dan untuk kalibrasi pada peralatan produksi kalibrasi disediakan konsumen harus sesuai spesifikasi

Kendala proses pemasangan dan harus sesuai batas toleransi yang dipersyaratkan

Perusahaan harus menyediakan tenaga ahli kalibrasi yang berkompeten dan bersertifikasi

Pengujian kalibrasi Proses pengujian peralatan yang melibatkan kalibrasi yang melibatkan pihak ketiga pihak ketiga harus diklasifikasi sesuai kebutuhan dan panduan mutu

Proses masih

Pemilahan limbah B3 memerlukan tempat penampungan sesuai ketentuan dan mengurangi ketergantungan pada pihak ketiga manual dan tidak ada tempat khusus untuk mengolah

budaya $5 \mathrm{R}$ 
Lampiran Tabel 2. Kesimpulan Saran Para Pakar dengan Metode Delphi

\begin{tabular}{|c|c|c|c|c|}
\hline No & & bone & Penyebab & Kesimpulan Saran \\
\hline & Machine & $\begin{array}{l}\text { Peralatan } \\
\text { produksi }\end{array}$ & $\begin{array}{l}\text { Mesin banyak } \\
\text { yang mengalami } \\
\text { kerusakan }\end{array}$ & $\begin{array}{l}\text { Kerusakan banyak terjadi } \\
\text { pada mesin utama dan } \\
\text { sparepart yang sudah } \\
\text { berumur lebih dari } 10 \\
\text { tahun, sehingga diperlukan } \\
\text { kontrol dan perawatan } \\
\text { secara rutin }\end{array}$ \\
\hline & & & $\begin{array}{l}\text { Mesin sudah } \\
\text { banyak yang tua } \\
\text { dan ketinggalan } \\
\text { zaman }\end{array}$ & $\begin{array}{l}\text { Kondisi mesin banyak yang } \\
\text { sudah tua tetapi masih } \\
\text { membutuhkan revitalisasi } \\
\text { teknologi dengan tingkat } \\
\text { produktifitas } \\
\text { memenuhi pangsa pasar } \\
\text { saat ini }\end{array}$ \\
\hline & & & $\begin{array}{l}\text { Memerlukan } \\
\text { pembiayaan } \\
\text { ekstra untuk } \\
\text { melakukan } \\
\text { perbaikan dan } \\
\text { perawatan }\end{array}$ & $\begin{array}{l}\text { Pembiayaan mesin } \\
\text { diperlukan pada perbaikan } \\
\text { dan perawatan sesuai } \\
\text { dengan seleksi yang } \\
\text { direncanakan perusahaan } \\
\text { dalam jangka panjang atau } \\
\text { sebagai biaya rutin dalam } \\
\text { perhitungan HPP }\end{array}$ \\
\hline & & & $\begin{array}{l}\text { Diperlukan } \\
\text { keandalan mesin } \\
\text { yang selalu } \\
\text { mempunyai } \\
\text { performance baik }\end{array}$ & $\begin{array}{lcr}\text { Keandalan } & \text { mesin } & \text { harus } \\
\text { didukung } & \text { SDM } & \text { yang } \\
\text { berkompeten } & & \text { untuk } \\
\text { menjamin } & \text { mutu } & \text { dan } \\
\text { ketepatan } & & \text { waktu } \\
\text { penyelesaian } & & \end{array}$ \\
\hline & & $\begin{array}{l}\text { Penerapan } \\
\text { teknologi } \\
\text { terkini }\end{array}$ & $\begin{array}{l}\text { Perlu } \\
\text { ditambahkan } \\
\text { software baru } \\
\text { untuk update } \\
\text { teknologi }\end{array}$ & $\begin{array}{l}\text { Penambahan software } \\
\text { diperlukan sesuai dengan } \\
\text { kompetensi inti dan } \\
\text { tuntutan bisnis yang } \\
\text { disesuaikan dengan } \\
\text { kebutuhan operasional dari } \\
\text { teknologi yang digunakan }\end{array}$ \\
\hline
\end{tabular}

Proses control dan Proses control dan program maintenance diperlukan maintenance plan maitenance system atau software sesuai kebutuhan

2 Method Standart proses Pengelolaan sisa Pengelolaan sisa material produksi material harus dilakukan sesuai SO yang berlaku

Pelaporan Pelaporan manufactuirng

Manufacturing data report diperlukan

Data Report dukungan dari Divisi 
Pengujian dan Supply manpower pengendalian hasil produk

Jaminan Kualitas untuk mendukung produktivitas

Diperlukan supply manpower untuk set produksi sesuai kebutuhan dan kompetensi yang memadai

Ketergantungan pada pihak ketiga untuk melakukan pengujian alat khusus diperlukan survey untuk mendukung sinergi dan efisiensi

3 Material Perolehan material

$\begin{array}{ll}4 \quad \text { Man Power } & \text { Pemenuhan } \\ & \text { dan } \\ \text { pengelolaan } \\ \text { SDM }\end{array}$

Pengembangan
kompetensi
SDM
5

Standart
produk sesuai
keinginan
pelanggan

Kurangnya ketersediaan SDM subkon dengan kualifikasi khusus Implementasi pengajuan pelatihan tidak yang permintaan Permasalahan transfer knowledge antar generasi

Standart
sertifikasi produk
(ASME)

Standart produk oil dan gas

Komponen
Keterlambatan material dan sparepart khususnya produk impor harus diatasi dengan kecepatan administrasi internal dan pemasok yang terpercaya Ketersediaan SDM harus disesuaikan dengan kebutuhan dan kompetensi untuk mendukung arah bisnis kedepan

Ketersediaan SDM subkon harus dikualifikasi khusus sesuai kebutuhan dan dikelola secara profesional Implementasi pengajuan pelatihan disesuaikan kebutuhan dan anggaran perusahaan

Permasalahan transfer knowledge disebabkan karena proses regenarasi yang terlambat dan tidak dalam kelompok kerja yang berkesinambungan

Penyesuaian standart produk international dibuat sesuai ketentuan trend produk pasar kedepan

Penyesuaian standart produk oil dan gas yang berlaku dan sesuai kebutuhan pasar Komponen material yang 


\begin{tabular}{|c|c|c|c|c|}
\hline & & & $\begin{array}{l}\text { material ada yang } \\
\text { disediakan } \\
\text { konsumen,mengal } \\
\text { ami kendala saat } \\
\text { dilakukan } \\
\text { pemasangan }\end{array}$ & $\begin{array}{l}\text { disediakan konsumen } \\
\text { harus sesuai spesifikasi }\end{array}$ \\
\hline & & & $\begin{array}{l}\text { Pemasangan } \\
\text { komponen dan } \\
\text { masuknya partikel } \\
\text { kecil dengan } \\
\text { selisih mikron }\end{array}$ & $\begin{array}{lr}\text { Kendala } & \text { proses } \\
\text { pemasangan harus } & \text { sesuai } \\
\text { batas toleransi } & \text { yang } \\
\text { dipersyaratkan } & \end{array}$ \\
\hline & & $\begin{array}{l}\text { Perawatan dan } \\
\text { kalibrasi pada } \\
\text { peralatan } \\
\text { produksi }\end{array}$ & $\begin{array}{lr}\text { Tenaga } & \text { ahli } \\
\text { internal } & \text { untuk } \\
\text { melakukan } & \\
\text { kalibrasi } & \end{array}$ & $\begin{array}{lr}\text { Perusahaan } & \text { harus } \\
\text { menyediakan } & \text { tenaga } \\
\text { kalibrasi } & \text { yang } \\
\text { berkompeten } & \text { dan } \\
\text { bersertifikasi } & \end{array}$ \\
\hline \multirow{3}{*}{6} & \multirow{3}{*}{$\begin{array}{l}\text { Mother } \\
\text { Nature }\end{array}$} & \multirow[b]{2}{*}{$\begin{array}{l}\text { Pemilahan } \\
\text { limbah B3 }\end{array}$} & $\begin{array}{lr}\text { Pengujian } & \\
\text { kalibrasi } & \text { yang } \\
\text { melibatkan } & \text { pihak } \\
\text { ketiga } & \end{array}$ & $\begin{array}{l}\text { Proses pengujian peralatan } \\
\text { kalibrasi yang melibatkan } \\
\text { pihak ketiga } \\
\text { diklasifikasi } \\
\text { kebutuhan dan panduan } \\
\text { mutu }\end{array}$ \\
\hline & & & $\begin{array}{lr}\text { Proses } & \text { masih } \\
\text { dilakukan } & \text { secara } \\
\text { manual dan tidak } \\
\text { ada } \\
\text { khusus tempat } \\
\text { mengolah }\end{array}$ & $\begin{array}{l}\text { Pemilahan limbah B3 } \\
\text { memerlukan tempat } \\
\text { penampungan sesuai } \\
\text { ketentuan dan mengurangi } \\
\text { ketergantungan pada pihak } \\
\text { ketiga }\end{array}$ \\
\hline & & $\begin{array}{l}\text { Penerapan } \\
\text { budaya } 5 \mathrm{R}\end{array}$ & - & - \\
\hline
\end{tabular}

